\title{
Serious fungal infections in Canada
}

DOI:

10.1007/s10096-017-2922-y

\section{Document Version}

Accepted author manuscript

Link to publication record in Manchester Research Explorer

\section{Citation for published version (APA):}

Dufresne, S. F., Cole, D. C., Denning, D., \& Sheppard, D. C. (2017). Serious fungal infections in Canada.

European Journal of Clinical Microbiology and Infectious Diseases, 36(6), 987-992.

https://doi.org/10.1007/s10096-017-2922-y

\section{Published in:}

European Journal of Clinical Microbiology and Infectious Diseases

\section{Citing this paper}

Please note that where the full-text provided on Manchester Research Explorer is the Author Accepted Manuscript or Proof version this may differ from the final Published version. If citing, it is advised that you check and use the publisher's definitive version.

\section{General rights}

Copyright and moral rights for the publications made accessible in the Research Explorer are retained by the authors and/or other copyright owners and it is a condition of accessing publications that users recognise and abide by the legal requirements associated with these rights.

\section{Takedown policy}

If you believe that this document breaches copyright please refer to the University of Manchester's Takedown Procedures [http://man.ac.uk/04Y6Bo] or contact uml.scholarlycommunications@manchester.ac.uk providing relevant details, so we can investigate your claim.

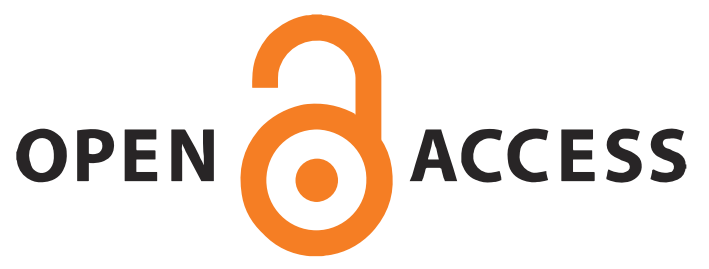


1 Title: Serious fungal infections in Canada

2

3 Authors: Simon F. Dufresne ${ }^{1}$, Donald C. Cole ${ }^{2}$, David W. Denning ${ }^{3}$ and Donald C.

4 Sheppard ${ }^{4}$

5

6

\section{Affiliation:}

1- Department of Infectious Diseases and Medical Microbiology, MaisonneuveRosemont Hospital Research Center, Université de Montréal, Montréal, Canada;

2- Dalla Lana School of Public Health, University of Toronto, Toronto, Canada;

3- The National Aspergillosis Centre, University Hospital of South Manchester, The University of Manchester, Manchester Academic Health Science Centre, Manchester, $\mathrm{UK}$;

4- Department of Microbiology and Immunology and Department of Medicine, Infectious Diseases and Immunity in Global Health Program, Research Institute of the McGill University Health Center, McGill University, Montréal, Canada.

\section{Corresponding author:}

Simon F. Dufresne

Department of Infectious Diseases and Medical Microbiology

\section{Hôpital Maisonneuve-Rosemont}

5415 boul. De 1'Assomption

Montréal (Québec) Canada, H1T 1M4

\section{sf.dufresne@umontreal.ca}
Fax: 514-252-3898 


\section{Abstract}

2 There are currently no nationwide epidemiological data on fungal infections in Canada. We

3 estimated the burden of serious fungal diseases using literature review and modelling, as per a

4 methodology previously described by the LIFE program (www.LIFE-worldwide.org). Among

5 the population of Canada (35.5 million in 2014), it was estimated that approximately $1.8 \%$ are

6 affected by a serious fungal infection. Recurrent vulvovaginal candidiasis, severe asthma with

7 fungal sensitization and allergic broncho-pulmonary aspergillosis are the most frequent

8 infections with a population prevalence of 498,688 (1,403/100,000), 73,344 (206/100,000)

9 and $61,854(174 / 100,000)$ cases, respectively. Over 3,000 invasive fungal infections are

10 estimated to occur annually, with an incidence of 2,068 cases $(5.8 / 100,000)$ of invasive

11 candidiasis, 566 cases $(1.6 / 100,000)$ of invasive aspergillosis, 252 cases $(0.69 / 100,000)$ of

12 Pneumocystis pneumonia, 99 cases $(0.28 / 100,000)$ of endemic mycoses and 63 cases

$13(0.18 / 100,000)$ of cryptococcosis. These estimates warrant validation through more formal 14 epidemiological studies in Canada.

15

16 Key words: fungal diseases, burden, epidemiology, Canada 
3 Canada is a high-income country with a gross domestic product of 1,551 billion dollars (USD)

4 in 2015 (GDP per capita, 43,249). Several studies have examined the epidemiology of fungal

5 infections in Canada, but most were local (single-centered, regional or provincial) and focused

6 on individual infections in specific populations. A single study reported on the burden of

7 invasive fungal infections at the national level, however these data are over 20-years-old [1], and relied largely on clinical microbiology laboratory records review. Since that time, the

9 Canadian population has expanded by $26 \%$; use of immunosuppressive therapies that increase the risk of fungal infection have risen in importance, e.g. solid organ and stem cell

11 transplantation and immunosuppressive biologic therapies; fungal diagnostics have improved; and medical care practices have evolved greatly. Hence, we sought to provide an estimate of the national burden of serious fungal infections.

\section{Material and methods}

16 The current study targeted serious fungal infections, which were defined as fungal-associated syndromes (infection or hypersensitivity) causing significant morbidity or mortality. The LIFE methodology (www.life-worldwide.org) was followed as described previously [2,3], with some modifications.

21 In brief, an annual burden was estimated for each targeted serious fungal disease and 22 presented as: i) absolute number of cases per year in Canada (representing either incident or 23 prevalent cases depending on the nature of the infection), and ii) annual rates (incidence or 24 prevalence), using the annual number of cases as the numerator and the entire Canadian population as the denominator. For simplicity, the 2014 Canadian population $(n=35,540,419$ 
1 [4]) was used regardless of the year from which the numerator data originated. To calculate

2 the absolute number of cases per year in Canada, data derived from various sources were 3 aggregated in a step-wise hierarchic fashion, starting with notifiable fungal diseases obtained

4 directly from national and provincial public health agencies, followed by local data from

5 individual centers or health authorities cited in peer review or grey literature and extrapolated

6 to the total Canadian population (with the exception of geographically-confined infections,

7 Cryptococcus gattii and endemic mycoses) and finally extrapolations from other countries' 8 estimates.

10 Sources included: Statistics Canada (total and adult female population [4], asthma prevalence 11 [5]), the Canadian Cancer Society (acute leukemia [6] and overall cancer incidence [7]), the 12 Canadian Institute for Health Information (number of solid organ transplants) [8], the 13 Canadian Bone Marrow Transplantation Group (number of hematopoietic stem cell 14 transplants), the Organization for Economic Co-operation and Development (number of 15 chronic obstructive pulmonary disease [COPD] admissions) [9], the Public Health Agency of 16 Canada (HIV prevalence and AIDS incidence) [10], the World Health Organization 17 (pulmonary tuberculosis incidence) [11] and Cystic Fibrosis Canada (cystic fibrosis prevalence) [12]. Of note, AIDS cases from the province of Québec are not currently reported to the Public Health Agency of Canada, so the number was calculated at pro rata of Québec population, assuming the same incidence as the rest of the country.

22 A map showing the geographic distribution of endemic mycoses was created using 23 SmartDraw (SmartDraw Software, LLC, San Diego, CA, USA).

\section{Results and Discussion}


2 Estimated annual numbers of cases of serious fungal diseases and the corresponding 3 population rates are summarized in Table 1 . The distribution of geographically-confined 4 mycoses is shown in Figure 1.

Opportunistic invasive fungal infections

The burden of invasive candidiasis (IC) was extrapolated from data reported from the Calgary health region and the Province of Québec $[13,14]$. In the first study, candidemia incidence was estimated at 2.8 cases per 100,000 person-year over a 5-year period, based on blood and 11 cerebrospinal fluid culture (approximately 93\% of cases were candidemia). Of note, incidence 12 was significantly higher $(3.7 / 100,000)$ during the latter 3 years of the study. In the second study, the reported annual incidence of candidemia was 3 cases per 100,000 population, with

$1450 \%$ of cases arising from intensive care units. These rates translate to at least 1,034 cases of candidemia each year in Canada. Deep-seated Candida infections such as peritonitis and endophthalmitis are accompanied by positive blood cultures in at most $50 \%$ of cases [15]. This observation is consistent with a recent nationwide German study which reported that the incidence of IC without candidemia was the same as candidemia [3]. Applying this ratio, a total of 2,068 IC cases are estimated to occur annually in Canada.

21 Invasive aspergillosis (IA) was largely reported in the main high-risk populations including 22 patients with hematologic malignancies, hematopoietic stem cell transplant (HSCT) recipients 23 and solid-organ transplant recipients (SOT), as well as patients with severe chronic 24 obstructive pulmonary disease (COPD). A recent study from a Montreal center found an 25 incidence of $8.9 \%$ among adult acute leukemia patients (both myelogeneous [AML] and 
1 lymphocytic [ALL]) [16], consistent with other international reports [17]. There were 1,215

2 cases of AML in Canada in 2010 [6], corresponding to approximately 108 cases of IA that

3 year. Since AML and ALL were reported to account for approximately $75 \%$ of IA cases

4 occurring among patients with hematologic malignancies [18], an additional 36 IA cases are

5 estimated to occur in patients with other hematologic malignancies. The incidence of IA

6 amongst patients undergoing SOT was estimated using data from a prospective North

7 American cohort study of these populations (12-month cumulative incidence: kidney, $0.2 \%$;

8 liver, 0.5\%; lung, 3.8\%; heart, 0.8\%; pancreas, 0.2\%) [19]. The incidence of IA after

9 allogeneic HSCT was estimated at $7.5 \%$ based on recent observational and interventional

10 studies [20-23]. In 2012, there were 1,358, 494, 194, 164 and 77 kidney, liver, lung, heart and

11 pancreas transplants in Canada, respectively [8], corresponding to an estimated 14 cases of

12 IA. A total of 1,200 allogeneic HSCT are performed annually in Canada (personal 13 communication, Canadian Bone Marrow Transplantation Group), resulting in an additional 14 estimated 90 cases of IA per year. Of note, large prospective cohort studies found that least $1520 \%$ of IA cases occur more than a year after SOT and HSCT [24,19], representing an 16 additional 26 cases. In addition, data from the North American Path Alliance registry showed 17 that $22.3 \%$ of IA cases were associated with other underlying diseases, including solid tumors, 18 HIV/AIDS and autologous HSCT, which translates to 78 cases. Hence, 352 IA cases are 19 estimated to occur annually amongst traditional immunocompromised populations. Finally, 2059,514 hospital admissions for chronic obstructive pulmonary disease (COPD) [9] account for 21 approximately 214 IA cases, or 3.6 cases per 1,000 admissions [25], resulting in a total of 566 22 IA cases annually.

24 Over a 10-year period (2003-2012), 264 cases of Pneumocystis pneumonia (PCP) were 25 diagnosed in single tertiary care centre in Montreal (personal communication, Dr M. Laskine, 
1 Centre Hospitalier de l'Université de Montréal). Using this center's estimated catchment

2 population of 3.4 million ( $41 \%$ of Quebec's population), one might expect as many as 252

3 cases per year across Canada.

4

5 A C. gattii outbreak has been ongoing in the province of British Columbia since 1999 [26]

6 (Figure 1). Between 2010 and 2013, a mean of 23 C. gattii infections per year were reported

7 to the British Columbia CDC [27]. During a 2-year period (1992-1994) prior to the C. gattii

8 outbreak, investigators had identified 81 cases of $C$. neoformans disease across the country

9 [1]. Assuming that $C$. gattii infections represent an increased burden of disease and that $C$.

10 neoformans infection rates remain unchanged, then at least 63 cryptococcal infections are

11 estimated to occur annually.

Endemic mycoses

Blastomycosis is endemic in the provinces of Ontario, Québec and Manitoba (Figure 1). It is considered hyperendemic in an area of northwestern Ontario [28]. In the former two provinces, recently published reports suggest that a mean of 44 culture-proven cases occur annually, [29,30]. In Manitoba where blastomycosis is a reportable infection, 19 cases were documented in 2013 [31]. Collectively, these data suggest an annual incidence of at least 63 cases of blastomycosis in these three provinces, hence in Canada.

Histoplasmosis occurs mainly along the Saint-Lawrence river valley, in Ontario and Québec

23 (Figure 1). Histoplasmin reactivity studies have shown a prevalence of $9-27 \%$ in southern 24 Québec [32-34]. The incidence of active histoplasmosis has been estimated at 27 cases per 25 year in Canada in a study spanning the 2-year period 1992-1994 [1]. 
2 Coccidioides immitis/posadasii is not indigenous in Canada, though cases of active coccidioidomycosis are imported. Studies have estimated there are between 2 and 9 cases of

4 coccidioidomycosis annually, largely in returning travelers [35,1].

Non-invasive pulmonary aspergillosis

8 Extrapolating from pulmonary tuberculosis 2014 annual incidence data $(n=1,065)$ [11], the

9 prevalence of cases of CPA following tuberculosis were estimated at 148 cases using a 10 previously reported model [36]. If prior pulmonary tuberculosis is the predisposing factor in 11 approximately $30 \%$ of cases of CPA [37], an estimated 492 new cases of CPA are expected.

13 ABPA burden was derived from the number of Canadian adults with asthma $(n=2,444,804)$

14 [5] and the number of patients suffering from cystic fibrosis (CF; $n=4,077)$ [12]. The 15 proportion of ABPA among asthma patients was estimated at 2.5\% [38] and 18\% in those 16 with CF [39], leading to a calculated national prevalence of 61,854 cases of ABPA. SAFS 17 burden was derived from asthma prevalence and estimated at 73,344 cases, assuming a severe 18 asthma prevalence of $10 \%$ of all cases of asthma and an Aspergillus sensitization prevalence 19 of $30 \%$ [40].

\section{Mucosal candidiasis}

23 RVVC is reported to affect up to $9 \%$ of women of reproductive age [41]. Canadian prevalence 24 of RVVC was calculated by applying 6\% to the Canadian adult women's population (between 2515 and 50 years old; $n=8,311,477$ [4]), yielding an estimated 498,688 cases present. 
2 In a systematic review, the prevalence of OC in cancer patients was estimated $7.5 \%, 39.1 \%$

3 and $32.6 \%$, before, during and after the end of treatment, respectively [42]. In Canada,

4196,900 new cases of cancer were estimated in 2015 [7]. Because the total number of patients

5 undergoing treatment and the survival rates are not known, only pre-treatment $\mathrm{OC}$ was

6 considered and the estimated prevalence was calculated at 14,767 cases of OC nationally.

7 HIV infection is responsible for an additional 752 cases, including approximately $1 \%$ of HIVpositive patients without AIDS and $18 \%$ of those with AIDS [43], based on a prevalence of 71,300 HIV-positive patients in 2013 in Canada including 218 with AIDS [10].

11 EC is an AIDS-defining illness affecting nearly 20\% of patients AIDS [44], thus at least 43 12 cases of EC are expected to occur annually in Canada. EC is also associated with other underlying conditions (eg. receipt of corticosteroids), but data on infection rates in these populations are not sufficient to inform accurate estimates.

Our study found that approximatively 3,000 invasive fungal infections occur annually in Canada, while over half a million people suffer from a chronic Candida or Aspergillus infection. Overall, RVVC is likely the most frequent serious fungal disease in Canada, with substantial quality of life impairment [45] and health costs [46], prompting the need for specific guidelines addressing diagnostic and treatment. Education on current guidelines for non-invasive forms of pulmonary aspergillosis is needed to increase awareness, diagnosis and treatment proficiency among health care providers. Invasive fungal infections annual 23 incidence $(8.3 / 100,000)$ is similar to that of invasive pneumococcal disease (8.9 in 2014) and 24 higher than invasive S. pyogenes disease (4.7 in 2013), infectious syphilis (5.1 in 2011), tuberculosis (4.4 in 2014) and HIV (5.9 in 2013) all regarded as important in Canada [47]. 
1 Amongst invasive infections, candidiasis is by far the most common disease, followed by

2 aspergillosis. Cryptococcosis, pneumocystosis and endemic mycoses are less commonly 3 encountered, consistent with findings of a recent large registry across North America [48].

4 Invasive fungal infections data from two Canadian centers have confirmed 90-day fatality 5 rates of $41 \%$ and $36 \%$ for IC and IA, respectively [49], over a thousand deaths annually in 6 Canada.

7

8 Our estimates of serious fungal infection burden in Canada provide an opportunity for both 9 health care providers and public health agencies to improve diagnostics, surveillance and 10 formal epidemiological studies, including measures of health care utilization. 
2 Table 1. Estimated annual burden of serious fungal diseases in Canada.

\begin{tabular}{|l|r|r|}
\hline \multicolumn{1}{|c|}{ Serious fungal infection categories and types } & $\begin{array}{c}\text { Proportion affected (per } \\
100,000 \text { population) }\end{array}$ & \# cases \\
\hline Opportunistic invasive fungal infections & 8,28 & 2,949 \\
\hline Invasive candidiasis (IC) without candidemia & 2,91 & 1,034 \\
\hline Candidemia & 2,91 & 1,034 \\
\hline Invasive aspergillosis (IA) & 1,59 & 566 \\
\hline Pneumocystis pneumonia (PCP) & 0,69 & 252 \\
\hline Cryptococcosis & 0,18 & 63 \\
\hline Endemic mycoses & 0,28 & 99 \\
\hline Blastomycosis & 0,18 & 63 \\
\hline Histoplasmosis & 0,08 & 27 \\
\hline Coccidioidomycosis & 0,03 & 9 \\
\hline Non-invasive pulmonary aspergillosis & 381,79 & 135,690 \\
\hline Severe asthma with fungal sensitization (SAFS) & 206,37 & 73,344 \\
\hline Allergic bronchopulmonary aspergillosis (ABPA) & 174,04 & 61,854 \\
\hline Chronic pulmonary aspergillosis (CPA) & 1,38 & 492 \\
\hline Mucosal candidiasis & $1,446,94$ & 514,250 \\
\hline Recurrent vulvovaginal candidiasis (RVVC) & $1,403,16$ & 498,688 \\
\hline Oropharyngeal candidiasis (OC) & 43,67 & 15,519 \\
\hline Esophageal candidiasis (EC) & 0,12 & 43 \\
\hline
\end{tabular}


Figure 1. Localization of geographically-confined mycoses in Canada. Colored areas

2 represent the approximate geographic distribution of three fungal infections: Blue: $C$. gattii;

3 Green: blastomycosis; Yellow: blastomycosis and histoplasmosis.

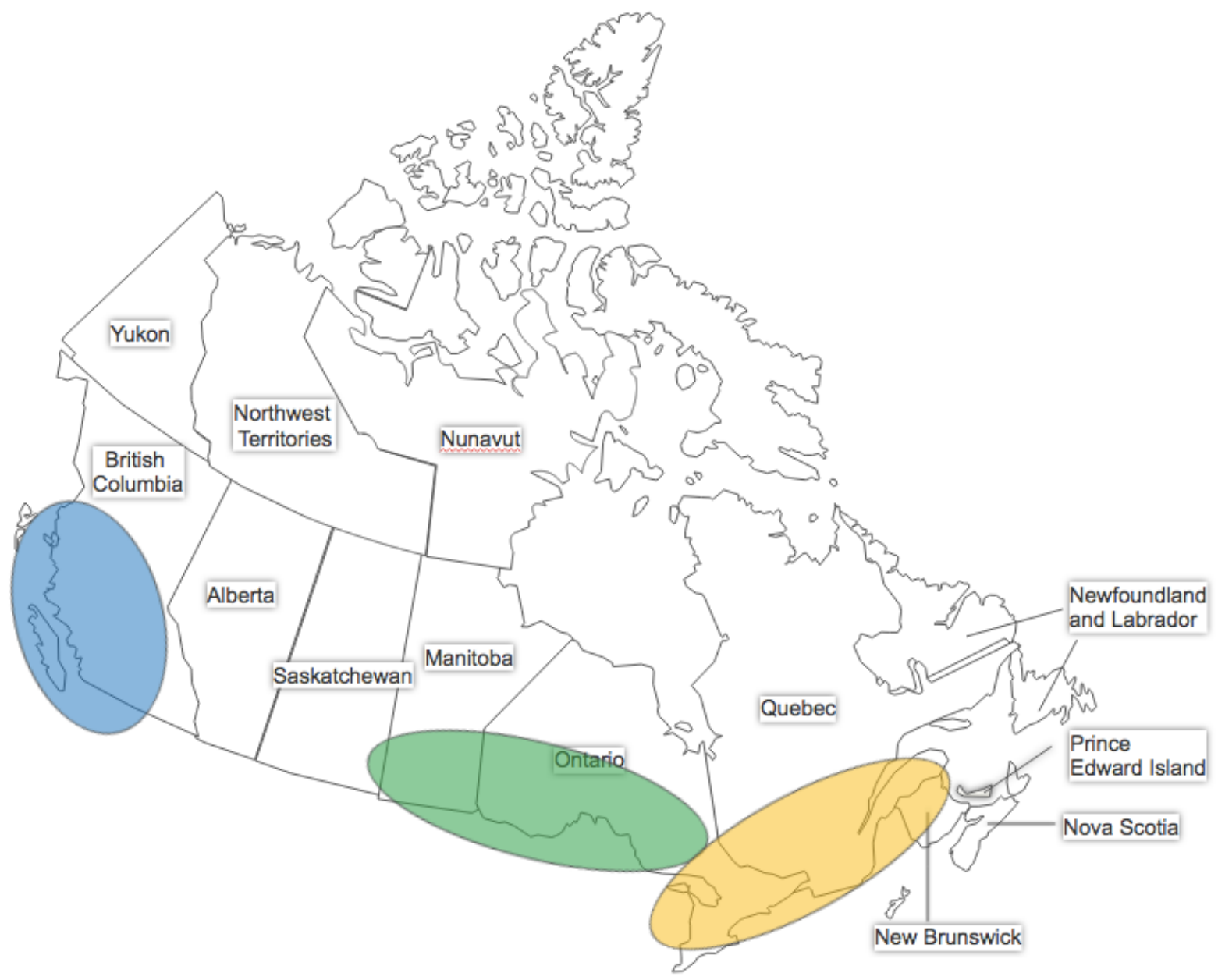




\section{References}

1. Nicolle L, Rotstein C, Bourgault A, St-Germain G, Garber G (1998) Invasive fungal infections in Canada from 1992 to 1994. The Canadian journal of infectious diseases $=$ Journal canadien des maladies infectieuses 9 (6):347-352 2. Rodriguez-Tudela JL, Alastruey-Izquierdo A, Gago S, Cuenca-Estrella M, Leon C, Miro JM, Nunez Boluda A, Ruiz Camps I, Sole A, Denning DW (2015) Burden of serious fungal infections in Spain. Clin Microbiol Infect 21 (2):183-189. doi:10.1016/j.cmi.2014.07.013 3. Ruhnke M, Groll AH, Mayser P, Ullmann AJ, Mendling W, Hof H, Denning DW (2015) Estimated burden of fungal infections in Germany. Mycoses 58 Suppl 5:22-28. doi: $10.1111 /$ myc. 12392

4. CANSIM Table 051-0001. Population by sex and age group (2014). Statistics Canada, 5. CANSIM Table 105-0502. Health indicator profile, two year period estimates, by age group and sex, Canada, provinces, territories, health regions (2012 bounderies) and peer groups (2013). Statistics Canada, Canadian Community Health Services, 6. Acute myelogenous leukemia statistics. (2015) Canadian Cancer Society. http://www.cancer.ca/en/cancer-information/cancer-type/leukemia-acute-myelogenousaml/statistics/?region=on. Accessed April 102015

7. Canadian cancer statistics 2015 (2015). Toronto, Ontario

8. Canadian organ replacement register annual report: treatment of end-stage organ failure in Canada, 2003 to 2012 (2014). Canadian Institute for Health Information, Ottawa, Ontario 9. Health at a glance 2013: OECD Indicators (2013). OECD, 10. HIV and AIDS in Canada: Surveillance report to December 31, 2013. (2014). Minister of Public Works and Gorvernment Services Canada, Ottawa, Ontario 11. Tuberculosis country profiles -Canada. (2014) World Health Organization https://extranet.who.int/sree/Reports?op=Replet\&name=\%2FWHO_HQ_Reports $\% 2 \mathrm{FG} 2 \% 2 \mathrm{~F}$ PROD\%2FEXT\%2FTBCountryProfile\&ISO2=CA\&LAN=EN\&outtype=html. Accessed August 16, 2016

12. The canadian cystic fibrosis registry: 2013 annual report (2015).

13. Laupland KB, Gregson DB, Church DL, Ross T, Elsayed S (2005) Invasive Candida species infections: a 5 year population-based assessment. J Antimicrob Chemother 56 (3):532537. doi:10.1093/jac/dki258

14. St-Germain G, Laverdiere M, Pelletier R, Rene P, Bourgault AM, Lemieux C, Libman M (2008) Epidemiology and antifungal susceptibility of bloodstream Candida isolates in Quebec: Report on 453 cases between 2003 and 2005. Can J Infect Dis Med Microbiol 19 (1):55-62 15. Clancy CJ, Nguyen MH (2013) Finding the "missing 50\%" of invasive candidiasis: how nonculture diagnostics will improve understanding of disease spectrum and transform patient care. Clin Infect Dis 56 (9):1284-1292. doi:10.1093/cid/cit006

16. Barkati S, Dufresne SF, Bélanger S, Vadnais B, Bergeron J, Labbe AC, Laverdiere M (2014) Incidence of invasive aspergillosis in remission-induction chemotherapy for acute leukemia: a retrospective cohort study in a single Canadian tertiary care center. Canadian Medical Association Journal Open 2 (2):E86-E93. doi:10.9778/cmajo.20130062 17. Pagano L, Caira M, Candoni A, Offidani M, Fianchi L, Martino B, Pastore D, Picardi M, Bonini A, Chierichini A, Fanci R, Caramatti C, Invernizzi R, Mattei D, Mitra ME, Melillo L, Aversa F, Van Lint MT, Falcucci P, Valentini CG, Girmenia C, Nosari A (2006) The epidemiology of fungal infections in patients with hematologic malignancies: the SEIFEM2004 study. Haematologica 91 (8):1068-1075 
18. Steinbach WJ, Marr KA, Anaissie EJ, Azie N, Quan SP, Meier-Kriesche HU, Apewokin S, Horn DL (2012) Clinical epidemiology of 960 patients with invasive aspergillosis from the PATH Alliance registry. J Infect 65 (5):453-464. doi:S0163-4453(12)00220-4 [pii]

10.1016/j.jinf.2012.08.003 [doi]

19. Pappas PG, Alexander BD, Andes DR, Hadley S, Kauffman CA, Freifeld A, Anaissie EJ, Brumble LM, Herwaldt L, Ito J, Kontoyiannis DP, Lyon GM, Marr KA, Morrison VA, Park BJ, Patterson TF, Perl TM, Oster RA, Schuster MG, Walker R, Walsh TJ, Wannemuehler KA, Chiller TM (2010) Invasive fungal infections among organ transplant recipients: results of the Transplant-Associated Infection Surveillance Network (TRANSNET). Clin Infect Dis 50 (8):1101-1111. doi:10.1086/651262 [doi]

20. Corzo-Leon DE, Satlin MJ, Soave R, Shore TB, Schuetz AN, Jacobs SE, Walsh TJ (2015) Epidemiology and outcomes of invasive fungal infections in allogeneic haematopoietic stem cell transplant recipients in the era of antifungal prophylaxis: a single-centre study with focus on emerging pathogens. Mycoses 58 (6):325-336. doi:10.1111/myc.12318

21. Harrison N, Mitterbauer M, Tobudic S, Kalhs P, Rabitsch W, Greinix H, Burgmann H, Willinger B, Presterl E, Forstner C (2015) Incidence and characteristics of invasive fungal diseases in allogeneic hematopoietic stem cell transplant recipients: a retrospective cohort study. BMC Infect Dis 15:584. doi:10.1186/s12879-015-1329-6

22. Wingard JR, Carter SL, Walsh TJ, Kurtzberg J, Small TN, Baden LR, Gersten ID, Mendizabal AM, Leather HL, Confer DL, Maziarz RT, Stadtmauer EA, Bolanos-Meade J, Brown J, Dipersio JF, Boeckh M, Marr KA (2010) Randomized, double-blind trial of fluconazole versus voriconazole for prevention of invasive fungal infection after allogeneic hematopoietic cell transplantation. Blood 116 (24):5111-5118. doi:blood-2010-02-268151 [pii]

10.1182/blood-2010-02-268151 [doi]

23. Montesinos P, Rodriguez-Veiga R, Boluda B, Martinez-Cuadron D, Cano I, Lancharro A, Sanz J, Arilla MJ, Lopez-Chulia F, Navarro I, Lorenzo I, Salavert M, Peman J, Calvillo P, Martinez J, Carpio N, Jarque I, Sanz GF, Sanz MA (2015) Incidence and risk factors of postengraftment invasive fungal disease in adult allogeneic hematopoietic stem cell transplant recipients receiving oral azoles prophylaxis. Bone Marrow Transplant 50 (11):1465-1472. doi:10.1038/bmt.2015.181

24. Kontoyiannis DP, Marr KA, Park BJ, Alexander BD, Anaissie EJ, Walsh TJ, Ito J, Andes DR, Baddley JW, Brown JM, Brumble LM, Freifeld AG, Hadley S, Herwaldt LA, Kauffman CA, Knapp K, Lyon GM, Morrison VA, Papanicolaou G, Patterson TF, Perl TM, Schuster MG, Walker R, Wannemuehler KA, Wingard JR, Chiller TM, Pappas PG (2010) Prospective surveillance for invasive fungal infections in hematopoietic stem cell transplant recipients, 2001-2006: overview of the Transplant-Associated Infection Surveillance Network (TRANSNET) Database. Clin Infect Dis 50 (8):1091-1100. doi:10.1086/651263 [doi] 25. Guinea J, Torres-Narbona M, Gijon P, Munoz P, Pozo F, Pelaez T, de Miguel J, Bouza E (2010) Pulmonary aspergillosis in patients with chronic obstructive pulmonary disease: incidence, risk factors, and outcome. Clin Microbiol Infect 16 (7):870-877. doi:10.1111/j.1469-0691.2009.03015.x

26. Kidd SE, Hagen F, Tscharke RL, Huynh M, Bartlett KH, Fyfe M, Macdougall L, Boekhout T, Kwon-Chung KJ, Meyer W (2004) A rare genotype of Cryptococcus gattii caused the cryptococcosis outbreak on Vancouver Island (British Columbia, Canada). Proc Natl Acad Sci U S A 101 (49):17258-17263. doi:10.1073/pnas.0402981101

27. British Columbia Annual Summary of Reportable Diseases 2013 (2014). Communicable Disease Prevention and Control Services, Provincial Health Services Authority Vancouver, British Columbia 
28. Dalcin D, Ahmed SZ (2015) Blastomycosis in northwestern Ontario, 2004 to 2014. The Canadian Journal of Infectious Diseases \& Medical Microbiology 26 (5):259-262 29. Morris SK, Brophy J, Richardson SE, Summerbell R, Parkin PC, Jamieson F, Limerick B, Wiebe L, Ford-Jones EL (2006) Blastomycosis in Ontario, 1994-2003. Emerg Infect Dis 12 (2):274-279. doi:10.3201/eid1202.050849 blastomycosis in Quebec, Canada, 1988-2011. Epidemiology and infection 141 (6):11431147. doi:10.1017/s0950268812001860

31. Manitoba Annual Summary of Communicable Diseases 2013 (2014). Government of Manitoba. Manitoba Health, Healthy Living and Seniors. Public Health and Primary Health Care Division. Public Health Branch. Epidemiology and Surveillance.,

32. Guy R, Roy O, et al. (1949) Histoplasmin sensitivity; preliminary observations in a group of school children in the Province of Quebec. Canadian journal of public health $=$ Revue canadienne de sante publique 40 (2):68-71

33. Leznoff A, Frank H, Taussig A, Brandt JL (1969) The focal distribution of histoplasmosis in Montreal. Canadian journal of public health $=$ Revue canadienne de sante publique 60 (8):321-325

34. MacEachern EJ, McDonald JC (1971) Histoplasmin sensitivity in McGill University students. Canadian journal of public health = Revue canadienne de sante publique 62 (5):415422

35. Sekhon AS, Isaac-Renton J, Dixon JM, Stein L, Sims HV (1991) Review of human and animal cases of coccidioidomycosis diagnosed in Canada. Mycopathologia 113 (1):1-10 36. Denning DW, Pleuvry A, Cole DC (2011) Global burden of chronic pulmonary aspergillosis as a sequel to pulmonary tuberculosis. Bulletin of the World Health Organization 89 (12):864-872. doi:10.2471/blt.11.089441

37. Smith NL, Denning DW (2011) Underlying conditions in chronic pulmonary aspergillosis including simple aspergilloma. Eur Respir J 37 (4):865-872. doi:10.1183/09031936.00054810 38. Denning DW, Pleuvry A, Cole DC (2013) Global burden of allergic bronchopulmonary aspergillosis with asthma and its complication chronic pulmonary aspergillosis in adults. Med Mycol 51 (4):361-370. doi:10.3109/13693786.2012.738312

39. Baxter CG, Dunn G, Jones AM, Webb K, Gore R, Richardson MD, Denning DW (2013) Novel immunologic classification of aspergillosis in adult cystic fibrosis. J Allergy Clin Immunol 132 (3):560-566.e510. doi:10.1016/j.jaci.2013.04.007 40. Agarwal R (2011) Severe asthma with fungal sensitization. Current allergy and asthma reports 11 (5):403-413. doi:10.1007/s11882-011-0217-4

41. Foxman B, Muraglia R, Dietz JP, Sobel JD, Wagner J (2013) Prevalence of recurrent vulvovaginal candidiasis in 5 European countries and the United States: results from an internet panel survey. Journal of lower genital tract disease 17 (3):340-345. doi:10.1097/LGT.0b013e318273e8cf 42. Lalla RV, Latortue MC, Hong CH, Ariyawardana A, D'Amato-Palumbo S, Fischer DJ, Martof A, Nicolatou-Galitis O, Patton LL, Elting LS, Spijkervet FK, Brennan MT (2010) A systematic review of oral fungal infections in patients receiving cancer therapy. Supportive care in cancer : official journal of the Multinational Association of Supportive Care in Cancer 18 (8):985-992. doi:10.1007/s00520-010-0892-z 43. Matee MI, Scheutz F, Moshy J (2000) Occurrence of oral lesions in relation to clinical and immunological status among HIV-infected adult Tanzanians. Oral diseases 6 (2):106-111 44. Buchacz K, Baker RK, Palella FJ, Jr., Chmiel JS, Lichtenstein KA, Novak RM, Wood KC, Brooks JT (2010) AIDS-defining opportunistic illnesses in US patients, 1994-2007: a cohort study. Aids 24 (10):1549-1559. doi:10.1097/QAD.0b013e32833a3967 
1 45. Zhu YX, Li T, Fan SR, Liu XP, Liang YH, Liu P (2016) Health-related quality of life as 2 measured with the Short-Form 36 (SF-36) questionnaire in patients with recurrent

3 vulvovaginal candidiasis. Health and quality of life outcomes 14:65. doi:10.1186/s12955-016$4 \quad 0470-2$

5 46. Fong IW (1996) Clinical and cost considerations in the pharmacotherapy of vulvovaginal 6 candidiasis. PharmacoEconomics 9 (6):497-505

7 47. Public Health Agency of Canada - Surveillance. (2016) Public Health Agency of Canada. 8 http://www.phac-aspc.gc.ca/surveillance-eng.php. Accessed 2016-09-16 2016

9 48. Azie N, Neofytos D, Pfaller M, Meier-Kriesche HU, Quan SP, Horn D (2012) The PATH 10 (Prospective Antifungal Therapy) Alliance(R) registry and invasive fungal infections: update 11 2012. Diagn Microbiol Infect Dis 73 (4):293-300. doi:S0732-8893(12)00239-8 [pii]

12 10.1016/j.diagmicrobio.2012.06.012 [doi]

13 49. Haider S, Rotstein C, Horn D, Laverdiere M, Azie N (2014) The Prospective Antifungal 14 Therapy Alliance((R)) registry: A two-centre Canadian experience. Can J Infect Dis Med 15 Microbiol $25(1): 17-23$ 